\title{
Catalyst and Instrument of National Growth: Interrogating the Significance of Entrepreneurship in Nigerian Economic Development
}

\author{
ONILEOWO, Teniola Temitope \\ Ekiti State University, Faculty of Management Sciences, Department of Entrepreneurship \\ ANIFOWOSE, Oluwafemi Dele \\ Ekiti State University, Faculty of Management Sciences, Department of Entrepreneurship
}

\begin{abstract}
Entrepreneurship as it is widely believed is a fueling developmental hub and cause of financial progression of any given economy. The general Entrepreneurial activities have been found to be proficient of creating optimistic and progressive impacts towards nation's economy and improved class of life expectancy of the people. This study based on this, sourced to look at the entrepreneurship as a catalyst and instrument of progress and improvement in Nigeria economy. The study make used of the secondary data and the outcome signposts that entrepreneurship has immensely contributed significantly to the employment generation and growth of Nigerian economy. Some of the major observation is that entrepreneurship development has massively enhanced job creation. And, however consequently lead to economic development. It is recommended that Nigerian should advance more especially some other economic opportunities while government should ensure the enabling environments for purposeful development of entrepreneurship practices.
\end{abstract}

Keywords: Entrepreneurship Development, Impact, Nigeria Economy.

DOI: $10.7176 / \mathrm{EJBM} / 12-3-13$

Publication date: January $31^{\text {st }} 2020$

\section{Introduction}

The economy nourishment, stability and progression can be measure through entrepreneurial development especially for the sustainability of individual and groups in a country. Meanwhile scholars has worked on entrepreneurship and widely found that it has potency in developing any country economy. The overview of the success recorded in the developed nations was most often linked to the success of entrepreneurship and which stands to be a pointer to economy development most especially the third world nations. Entrepreneurship is being regarded as "source of economic growth" (Adejumo, 2000). This is due to the significant emphasis on its role towards developing a country's economy. It is also linked to the activities that are capable to influence the life and economy of a given country.

According to Adejumo (2000) entrepreneurial undertakings have been establish to be adept of creating optimistic influences on the economy of a nation and the worth of life expectancy of the people. The linkage concerning entrepreneurship and economic development is made known when entrepreneurs exploit upon turnover prospects and in the course of making the economy more fruitful by building extra economic undertakings which always create employment opportunities and increase the gross domestic product GDP (Nwachukwu, 2012). Some third world countries like Nigeria, is abundantly rich in human and natural resources. Not only that, it is also blessed with variety of minerals deposits such as coal, petroleum, natural gas, precious metal, tin, crystal and an enormous Agricultural farm lands. And, in spite of these, Nigeria is not economically and technologically advanced in the face of all these endowments because of lack of industrial infrastructural base and among others. However, these constrains has tremendously limited the expansion of entrepreneurial activities in Nigeria, consequently, Nigeria economy remains undeveloped. Meanwhile, Nigeria is blessed with numerous commercial and asset proficiencies due to the over-abundant, energetic and energetic human and natural resources (bits and pieces it) possesses. Tapping these resources requires the ability to recognize potentially useful and economically viable fields of endeavors'.

As a result, there have been notable attempt to the development in entrepreneurial activities and innovative skill in Nigeria enterprises within the following areas: food process, extracting, germ-stone acerbic/improving, power compeers, heave business (consignment and commuters), producing and upkeeps of GSM fittings and the letterpress and hawking of recharge cards, assembly and repairs of pipelines, make a hole, processing bye products, refuse disposal, and re-cycling, drainage/sewage construction job, banking, insurance and stock transaction, machines and tools fabrications. Entrepreneurial development is therefore seen as conceived programmed activities that could enhance the knowledge (bulk of knowledge), skill, behaviours and attitudes in creation society's riches for human capability and building. Therefore, entrepreneurial development is perceived as the bedrock for capacity building and economy development. Recent Development of Entrepreneurship in Nigeria 
The study of Entrepreneurship as an aspect of human endeavor has received amassed interest of scholars, academicians and policy builders everywhere across the globe. Also, the protagonist of government in promoting entrepreneurship development in Nigeria has become pronounced towards the end (1967-70) Nigeria civil war. Since the mid-1980s there has been improvement in the commitment of government towards entrepreneurship development particularly since the overview of the Structural Adjustment Program (SAP) in 1986.

Meanwhile, the idea of entrepreneurship development is thought to be the key to poverty eradication, employment generation and speedy economic development. Entrepreneurship is seen not only as being efficient in tackling the issue of unemployment, poor financial condition and under-development within the developing nations, however as a technique for speedy economic development in each industrialized and unindustrialized nations has hence supported the growth of entrepreneurship developments (Schumpeter, 1934; Harper, 1991; Morris \&Lewis, 1991; Hamilton, 2000; Clausen, 2006; Praag \& Versloot, 2007). The various governments in Nigeria have, ended the preceding three decades, having realized the significance of entrepreneurship as instrument of progression and enlargement of any economy now engaged in developing policies and programmes, that most often geared toward developing entrepreneurship through the creation of small and medium scale enterprises (SMEs).

The establishment of the present National Directorate of Employment (NDE), National Open Apprenticeship Scheme (NOAS) and, the Small and Medium Enterprise Development Association of Nigeria (SMEDAN) were a testimonies to these programmes (Thaddeus, 2012). Basically, the Nigerian government stimulates entrepreneurial philosophy through creativities that shape business confidence, positive outlook, egotism in accomplishment, sustenance and reassurance of innovative ideas, social obligation, supplying technological supports, enhancing inter-firm linkages and stimulation of study and development. In the early $2000 \mathrm{~s}$, came the introduction of entrepreneurship studies into the Educational system of Nigeria as a compulsory course to be undertaken particularly by students in the higher institutions. The Centre for Entrepreneurship Development(CED), was established with the mandate of training and inspiring students of higher institutions (particularly in the arena of science, engineering and technological (SET)) to acquire entrepreneurial, innovative, and management skills, realizing the poor increase in the neck and neck of unemployment and poverty rate in Nigeria which has stirred the interest of university graduates as well as young school leavers who are unable to get a white-collar jobs of their own to turn over into entrepreneurship.

This reflect one of the goals of the Centre for Entrepreneurship Development (CED) to make the unemployed graduates to be self-employed, so that at the end of their programme of study, graduates of the tertiary institutions would be able to set up their own business with the aim of contributing to the economy as well as to generate job openings for others and to create wealth (Thaddeus, 2012). In addition, the idea of entrepreneurship development in Nigeria became relevant immediately after the expiration of the Nigerian civil war and at the expiration of the war, the 2d National Development Plan concentrated on developing the 3Rs objectives of Rebuilding, Redevelopment and Appeasement. Entrepreneurial activities is commonly practiced by micro and small scale businesses and thus, SMEDAN's effort is to direct concentration on the event of micro, small and medium-scale enterprises (MSMEs) wherever it co-ordinates and incorporates MSME activities so as to develop their full potential and competitiveness (Thaddeus, 2012).

The cheering news here is that Small and Medium Enterprises Development Association of Nigeria business (SMEDANs) has the capability of growing to become a large-scale entrepreneurship if the correct parameters like finance, infrastructural development, favorable government policies, and adequate preparation together with sufficient information of the business are thought satisfactorily. However, Nigeria has experienced an economic development system of industrialization as a result of economic process, and industrialization owing to the product of technical progress and investment. Technical progress or capital growth on the other side is thought to be, and also the results of, entrepreneurial effort within the economy. There are evidences from around the developed countries stating the fact that economic evolution is the result of the availability of quality and competency of the entrepreneur within the country. Hence, the need for the Nigerian government to stimulates and gives support to indigenous entrepreneurs after independence in 1960. The government thereby embraces the multilateral relationship between entrepreneurship, industrial and economic development. The government, within the last forty years had taken varied steps, together with financial, business and industrial policy measures to support the development of Small and Medium Scale Enterprises (SMEs) by establishing varied support institutions designed to provide succor and to assist SMEs to cope with a number of the obstacles on their growth path. Specifically, the government has been active within the following areas: supporting funding for the establishment of industrial estates to cut back overhead costs; - Support the creation of the institution of industrial financial institutions, comprising of Small Scale Industry Credit theme (SSICS), Nigerian Industrial Development Bank (NIDB) and the Nigerian Bank for Commerce and trade (NBCI) which is to offer long- term credit. Support the creation of the institution of the National Economic Reconstruction Fund (NERFUND), this is to offer medium to long- term indigenous likewise foreign loans for small and medium scale businesses. Facilitating and guaranteeing external finance by the World Bank and alternative international financial institutions; - To support the creation of the 
institution of the National Directorate of Employment (NDE), the Nigerian Export-Import Bank (NEXIM), Industrial Development coordinating Centre (IDCC), Peoples Bank, Community Banks, Construction Bank, likewise Family Economic Advancement Programme (FEAP) and State Ministries of trade SME schemes etc. Delivery of technical training and consultative services through the industrial Development Centers and so on. Meanwhile, the aforementioned supporting institutions and alternative incentives provided by the governments have assisted in enhancing the performance and activities of entrepreneurship within the economy.

Consequently, growths in small scale enterprises lead to increase in national income, employment generation, and concrete entrepreneurial base and viable economic growth within the country. The craving for entrepreneurship development within the country nowadays is necessitated by the fact that entrepreneurship development is considered to be a major factor for a sustainable economic growth and especially a permanent cure for long-lasting starvation and deficiency caused by lack of employment. The availability of skillful entrepreneurs within a country will lead to inspiration which implies that a rise in material wealth (opportunities) ends up in increasing the aspirations of the people. Entrepreneurs have been acknowledged as agents that lead to economic revolution that has brought improvement on the economy customary of corporeal of people everywhere.

Entrepreneurship Development: A background view Entrepreneurship all over the world is viewed as the theory of discovering and managing a business venture so as to make profit by taking several risks in the corporate world. This describe a situation whereby an individual who has found and ready to undertake an entrepreneurial activities as well as to assume all risks and reward of the venture is seen as an entrepreneur.

According to Hornby (2006), entrepreneur was defined as that individual who makes money by opening up and in succession businesses, particularly when this involves captivating financial risks. This is reflected in the physiognomies of an entrepreneur in his ability to identify an innovation so as to enable him seize an opportunity, mobilize finance and management skills as well as assume calculated risks to create bazaars for new foodstuffs, processes and services. While Amacchina \& Nwaddozie (1995), put that an entrepreneur is that individual who is willing and able to take business risks for gainful purposes. This means that, the idea of entrepreneurship bothers on those entrepreneurial activities that focus majorly on operational undertakings of a business enterprise which include such activities as proof of identity of investment prospects to daring act for profit, promotion and institution of the business enterprise, pooling of the varied scare resources needed for production and distribution of products and services, organization and management of the human and material resources for the achievement of the purposes of the enterprises, risk bearing and innovation.

Going by the assertion of the researchers above, they were able to establish that entrepreneurship is about being ready to take up a risk by pooling varied and scarce resources to set up a business enterprise and opportunities to exploits profits. Abraham Maslow, quoted in Stephens, 2000 affirmed that the entrepreneur is someone who can "recognize change, enjoy it and improvise without being cautioned". He further pointed out that, the entrepreneur is a "here-now" creator, an improviser, who is not afraid of being viewed as operating in conflict with general practice and belief (Stephens, 2000). This gives a clear depiction of an entrepreneur as big shot that is determined to achieve success against all odds; he sees every obstacle as a challenge and is ready to turn this challenge into an opportunity by providing a solution to the situation at hand which in turn create more opportunities and enable him gain more grounds.

Drucker (1985) held that, an entrepreneur is an individual who fills the role of an entrepreneur (a visionary who does accept hands on responsibility for creative innovation in an organization) outside the organization. To buttress this assertion, the entrepreneur is seen as someone who possesses the ability to conceive meaningful ideas, invents, as well as identifies ways by which these ideas can be used to achieve success. He engages in the activities by bringing new products and services into the market in order to generate satisfaction for his immediate environment. He is someone who exhibits the skill to identify and estimate business opportunities, as well as to put together necessary resources to initiates applicable action for success.

In view of the above affirmations made by these scholars, it was established that, entrepreneurship is about being goal-oriented, willing and ready to take action that will lead to triumph in the realization of goals and objectives. According to Vanderwerf and Brush, 1989 quoted in Akanni, 2010 after appraising twenty-five definitions, resolved that entrepreneurship is a business goings-on comprising of some connections of the following behaviours: creativity, innovation, general management, risk bearing and intention to realize high levels of growth. Hence, having considered the views by various scholars aforementioned, all points to the fact that entrepreneurial activities has been proven beyond reasonable doubt to have an optimistic effect on the economy of a nation and also efficient in creating job opportunities among others; thereby decreases the level of poverty among the citizens of such nation as well as boost the uncultured domestic economy product.

Entrepreneurship Roles in Economic Development Entrepreneurship has been renowned as a very important facet and in effect of organization and economies (Dickson, 2008). This means that Entrepreneurship is thought as one of the most significant contribution in the economic development of a country. It shows a vital role not solely within the development of industrial sector of a country but similarly within the farm and service sector. According to (Dickson, 2008), the researcher acknowledged that entrepreneurship has been documented as a very 
important feature and operative of organization and economies. Its contribution towards the development of a country has led to creation of new job opportunities, wealth creation, poverty reduction and generating financial gain for every government and other people. Joseph Schumpeter in 1934 upheld that entrepreneurship is very essential to the growth and development of economies (Keister, 2005, quoted in Garba, 2010). Entrepreneurship has since reduces poverty and contribute vastly to the economic level of a country through the products or services created that are being purchased by customers, through generation of economic activities like shopping, selling, marketing, payment of taxes to the government, undergoing company social responsibility to the varied stakeholders within the community during which the enterprise is operated. There are various important roles that entrepreneurship plays in the economic development of a country which are discussed under the following headings:

1. Preferment of Small Scale Businesses It is widely acknowledged that Entrepreneurship in any country stimulates and gives strength to small and medium-sized enterprises (SMEs). Schaper (2002), pointed out that, countries that have created economic breakthroughs within the last twenty years demonstrate absolutely that, entrepreneurship stood as a backbone of economic process and development of such country. This buttress the basic fact that, the extent of entrepreneurship development in a country is set by the amount of small and medium sized enterprises (SMEs) that are obtainable in such country. That is, the more SMEs a country have the more chances that the country will attain economic progress. Small and Medium Enterprise (SMEs) occupy an area of pride in nearly each country or a nation. SMEs therefore represent an authentic vehicle for the accomplishment of national economic objectives of and employment peer group and poverty reduction at low investment price and similarly the development of entrepreneurial capabilities as well as local technology. There are other essential advantages of SMEs which are entree to the infrastructural facilities induced by the reality of such SMEs in their ambiances, the motivation of economic activities like suppliers of varied things and distributive crafts for things created and or required by the SMEs curtailing from rural urban migration., improvement of standard of living of the workers of the SMEs and their hooked on similarly as people that are directly or indirectly related to them.) Over the years, Small and Medium Enterprises (SMEs) in Nigeria occupies an extremely important position in Nigeria economy. From the above view point, SMEs can be seen as one of the required condition of economic development in a country even though within the developed countries like the USA, where huge firms are dominant, SMEs still play enormous role within the country's economy.

2. Generation of Employment Across the globe, employment generation is one of the major goals of any government seeking economic development in all spheres and most importantly support reasons for encouraging the promotion and development of Entrepreneurship? SMEs accounts for well above half-done of the whole shares of employment, sales and value added (Davis, Haltiwagner, Schuh, 1993). From the perspective of economic development, small businesses produce nearly half of the new jobs within the economy, and it's presumed that they are respectable jobs (Davis, Haltiwagner, Schuh, 1993; Edmiston, 2007). SMEs build the most practicable and authentic vehicle for self-sustaining manufacturing expansion, as they enjoy the ability to provide a homegrown enterprise culture to a larger extent than the other strategy. According to Hallberg (1995), In South American nation, corporations with fewer than fifty staff accounted for $90 \%$ of corporations and $50 \%$ of employment in 1980; in Asian nation, enterprises with fewer than one hundred staff accounted for $99 \%$ of enterprises and 58\% of employment in 1986(SMECORP, 2011). SMEs represent the sub-sector of special emphasis in any significant economic restructuring set up that bull's eye employment generation, financial condition relief, food protection and rapid industrialization. Researchers are of the opinion that improving the performance of small business and authorizing the advancement of entrepreneurship would be a noble strategy to contribute and promote economic development (Snodgrass \& Biggs, 1996). Thus, create the room for employment opportunities within the country. Entrepreneurs help to generate employment both orthodox and meanderingly. Directly, self-employment as business person and indirectly by beginning several industrial units, they provide jobs to millions of people. Therefore entrepreneurship is observed as the best method to combat the mischievous unemployment within an economy.

3. Poverty Alleviation An entrepreneurial activity has help to promote the performance of small business operation worldwide. The growth of SMEs is perceived as a means to speed up the attainment of varied socioeconomic goals, together with poverty alleviation (Cook \& Nixson, 2000). This reveals that, the poverty level in the economy is reduced to minimal, through the promotion of SMEs which plays a considerable character in the development of any country. SME promotion is considered to be one of the furthermost real poverty alleviation instruments because it's going to return something back to the economy hence improve the living standard of the people. Kongolo (2010), put that, a rise in the existing standards of the people is the main concern of any development practice and with SMEs, this would go on an lengthened way in the attainments of socioeconomic growth and development. Income distribution Entrepreneurial activities through the performance of SMEs are commonly thought to contribute to additional equal distribution of income or capital. The SME managers and personnel are 
assumed to be in the minor half of the income dissemination; likewise, promoting the expansion of SMEs could generate additional distribution of income thereby increases the standard of living of the people as well as attain a high degree of output and fitness. Thus, the improvement of SMEs would facilitate the flow of income among many people which is linked to the fact that, $65 \%$ majority of the Nigeria SMEs owners are living in the rural areas, in narrowing the gap between urban and rural development and to monitor social inequities and migration (Pansiri \& Temtime, 2008) promotion of the growth of SMEs ought to be a policy priority of every country that desires development.

5. Transformation of indigenous Technology According to Kongolo (2010), the researcher asserts that, all economies have transited from domestic artificer industries over time to the contemporary industrial set-up that has witnessed incredible upgrading of skills, machinery and equipment, and management practices. This reflects the stimulus of entrepreneurship through SMEs brought about the introduction of technology and innovation. History has proven that almost all of today's big companies began as small corporations. These embrace Guinness of Dublin and Philips international of the Netherlands; likewise Sonny and Honda of Japan. Unindustrialized countries can as well borrow from the skill of these colossuses and use it to make a case for conducive, friendly and favourable atmosphere which could assist small and medium enterprises to graduate from locally based method of operation and adapt foreign technologies to modernize their method and use it to develop the business.

6. Production of intermediate Good The significance of entrepreneurship through SMEs activities is widely recognized in its production of intermediate and finished goods required by larger enterprises and within the economic system. These embrace raw materials, machinery and equipment, spare components and house merchandise. The deliveries to the large companies is done through sub-contracting that permits smaller enterprise to provide their wants, rather than compete with them in the assembly of finished goods where small enterprises would be comparatively at disadvantaged. The mutuality of the subdivision affords the recessive and accelerative links that is required for the economy self-dependence and sustenance. Within the cutting-edge economies, this dependent relationship is thus, the industrialized sectors widely rely on every alternative for survival. In Japan, for instance, near seventy percent of the worth of exports of large corporations are products produced by SMEs (ADCG, 2000).

7. Reduces attentiveness of Economic power is the natural upshot of business and commercial activity. Industrial development ordinarily results to attentiveness of economic power within the hands of a small number of individual which result in high growth of monopolies. In a bid to curtail this disadvantage, a huge number of entrepreneurs must be trained so as to help control the attentiveness of economic power amongst the population.

8. Promotes Capital Formation Entrepreneurs endorse investment formation by assembling the idle savings of public. They use their own funds and in most cases borrowed resources for establishing their enterprises. Such kind of entrepreneurial activities result to price addition and creation of wealth that is extremely essential for the commercial and economic development of the country.

9. Promotes Balanced Regional Development Entrepreneurs help to get rid of local disparities by establishing industries in less industrialized and backward areas. The expansion of industries and business in these areas attract a large range of public advantages like road transport, health, education, amusement, etc. Establishing of other industries pave the way for new development of backward areas and thus promotes stable regional development. As a result entrepreneurs grow at a quicker rate, in view of accelerating rivalry in and around cities; they are required to found their business enterprises within the smaller cities far from huge cities. This will in turn helps in promoting the development of backward regions.

10. Promotes Country's Export Trade Entrepreneurs facilitate in promoting a country's export-trade, which acts as a very important ingredient of economic development. They manufacture goods and services in mass with the aim of making more profit of foreign exchange from export so as to combat the import dues demand. Thus, import substitution and export promotion guarantee economic independence and development.

11. Raising the quality of Living Barreto (2014) contends that entrepreneurship through job and wealth creation raises the quality of living of individuals. Owing to higher financial gain earning and easy access to disposable income, they are able to afford the essential necessities of life like housing, consumer goods and food, education, proper healthcare delivery, etc.

12. Creating innovation an entrepreneur is someone who perpetually explores for changes as well as combines the factors of production. Not only that, he introduces new concepts and new combination of things. He also introduces 
newer ideas coupled with newer technique of production of products and services. By performing this function, an entrepreneur stimulates economic development through innovation.

13. Entrepreneurship puts new business concepts into practice in performing this function; an entrepreneur creates jobs that facilitate personal development. With their innovative and disrupting concept s, entrepreneurs also have the ability to tackle social issues too. Though it's a worthy pursuit to think about; considering the impact of entrepreneurship from one generation to another and the principles that entrepreneurship is a catalyst of economic development. On the entire, the role of entrepreneurship in economic development of a nation will best be place as "an economy is the result for which entrepreneurship is the origin"

14. Facilitates Overall Development Entrepreneurs act as facilitating instrument for change which ends in chain reaction. Once an enterprise is set up, the procedure of industrial development is put in place. This unit will help to generate demand for numerous forms of units needed by it and there will be such a large amount of different units that need the output of this unit. As a result, this ends up in overall development of a region because of the increase in demand and putting in place of additional units. Through this means, the entrepreneurs increase their entrepreneurial activities thereby creating an atmosphere of enthusiasm as well as initiating the motivation and expansion for overall growth of the area.

\section{Impact of Entrepreneurship on Economic Development.}

Great interest in entrepreneurship and its impact on economic development has widely spread over the last two decades. This interest stems from many sources not the least of which has been from knowledge that rest on the shoulders of scholars like Adam Smith ( 1776), and Joseph Schumpeter (1983) and Israel Kirzner (1973) to mention a few. In recent times, an enormous growth of information and knowledge driven by developments in the competitive markets and entrepreneurial activities in promoting economic development has not solely contributed to the growth but also to the ability to manage and maximize opportunities in the manufacturing and services production. This has however created many new products and services that could not have been imagined even some years past. The huge growth of the knowledge of entrepreneurship has created expanded opportunities for innovation, economic development and related growth at a seemingly ever increasing rate and especially seek out improvement in knowledge and technology, general welfare, improved relations among stakeholders i.e.( Consumers, Employees, Competitors, Society, Government) positive movement in the direction of organization. This was affirmed by (Acs and Szerb, 2010), defined entrepreneurship as creation and growth of new institutions or corporations has been increasing throughout the globe since the early 1990s. Over the years in developing countries, the primary barrier to economic development is usually not most associated with insufficient capital, labour or land; however it's the shortage of dynamic entrepreneurs that may bring these along and also the markets and mechanisms that may facilitate them during the time of carrying out this task. According to Schumpeter, the researcher states that, output growth in an economy depends significantly on the entrepreneur.

That is, the degree of performance of entrepreneurial activities within a country will help boost the economic development of such country as a result will yield more output growth. Meanwhile the quality of entrepreneurs within a country determines level of capital's growth rate whether speedily or slowly and whether or not the expansion involves invention where new products and production techniques are developed. This means that, the distinction in economic growth rates of countries of the globe is basically due to the standard of entrepreneurs available in those countries. Therefore, production factors of land, labour and capital are said to remain inactive without the entrepreneur who organizes them for productive ventures. This however emphasize the significance of the entrepreneur who is regarded as agent of innovation progression and technical advancement within the economy of any country. The development and utilization of their technical and commercial skills resulted into creating growth potential in micro, small and medium-scale enterprises that helps raise the growth of the economy. The present economy of nowadays is knowledge-driven operational on the logical and innovative thoughts of the entrepreneur. Business operations today have become informal and oriented tending towards survival and selfemployment.

Technical progress basically results in increase in level of production, employment of labour, stimulation of export and overall growth of gross domestic commodities. The impact and contribution of entrepreneurship to the expansion and development of Asian countries (China, Malaysia and Singapore) and African countries (South Africa and Nigeria) cannot be over accentuated. In Nigeria, entrepreneurship development innovations are recognized almost in every aspects of the economy promoting the economy thru; small business, micro finance, small and medium industries, information/telecom services, personal services in food vending/restaurant, clothes creating, embroidering, agricultural turn out, music and film production. Entrepreneurship and economic development are Interdependent, thus implies that economic development takes place once a country's real financial gain increases over a certain period where within the protagonist of entrepreneurs is an essential part. This stresses the effect of entrepreneurship as that which cannot be undermined in any given economy. According 
to Mark Carson as quoted by Desai (2009), the researcher laid emphasis on the demand for entrepreneurship stems from the necessity for improvement. The impact of entrepreneurship development on the economy all over the world cannot be over accentuated as it is efficient in creating jobs for Nigeria youth likewise; economic progression and improvement of Nigeria. However, Bamiduro (2001) as cited by Aremu (2004) stated that 'A motivating force within the current economy for the past few years and also the anticipated future is entrepreneurship'. Entrepreneurs are meeting the desires of Nigerians through the creation of thousands of new business every year. It has been established that new business (mostly small industry) provides the bulk of employment opportunity for the youth within the country. All over the globe as proof in Asia (The Asia Tigers), Entrepreneurs are considered as a vehicle for speedy industrialization, sustainable economic development, poverty alleviation and employment generation Aremu (2004). Conclusion The conclusion is that the influence of entrepreneurship development on the Economy has very important contributions in promoting small business, promoting country's export trade, employment generation, income dispersal, creating innovation and transformation of indigenous technology.

A well-adjusted approach to fostering entrepreneurship will certainly lead to an optimistic bearing on economy and society. Entrepreneurship results in job creation for Nigeria youth and also stimulation of growth. It is no gain stressing the actual fact that entrepreneurship contribute considerably in areas of employment creation, promoting growth, and industrial development, poverty alleviation, creating innovation, promoting capital formation, promoting country's export trade and promoting balanced regional development. Entrepreneurship development has shown to be a viable instrument for economic development; thus the effort of government and other establishment ought to be channeled towards the significant development of entrepreneurship practices. The study has shown that the influence of entrepreneurship development results in economic development, job creation, economic sustainability, individual self-sufficiency, improved standard of living, higher awareness and practice. The insinuation of the study shows that entrepreneurship development consistently results in job creation that consequently results in economic development. Hence, Nigeria youth ought to exploit the varied economic opportunities within the economy to their advantage. Assistance should be given to the unemployed youth in form of credit facilities to enable them start a small business rather than roaming round the town in search of white collar job. Therefore, to ensure a suitable and viable entrepreneurship development the federal government with various divisions of government in Nigeria have a duty to make available the enabling atmosphere for the activities of entrepreneurs like provision of infrastructures, enacting and formulating of laws and policies that can support entrepreneurship development within the country. And, since, the developments of entrepreneurship growth become very essential for the economic freedom of country and in order to enhance and promote the development of entrepreneurship, the Nigeria Government should therefore:

a. Direct effort to the purposeful development of entrepreneurship practices

b. Engage in developing policies and programmes geared toward developing entrepreneurship like SMEs.

c. Make available factors like finance, good infrastructures, government policies etc. that can facilitate the growth and development of entrepreneurship within the country.

d. Focus on developing entrepreneurship since it has the potency of developing a country' economy.

e. Give a strong support to indigenous entrepreneurs so as to encourage the upcoming generation as well as direct their interest towards exploring the fields of entrepreneurship and also to be able to stand on their own.

\section{References}

Abimbola, O. H. \& Agboola, G. M. (2011). Environmental factors and Entrepreneurship development in Nigeria. Journal of Sustainable Development in Africa, 13(4), 166-176.

Acs. Z. J., and Szerb, L,. (2010): Global Entrepreneurship and the U. S. Economy* Washington D.C., SBA Office of Advocacy, https://thegedi.org/wp-content/uploads/2010/04/SBA_Gedi 1 .pdf

Adejumo, D. G., (2000), "Indigenous Entrepreneurship Development in Nigeria”, in Advanced Management, Department of Business Administration, University of Ilorin

Adejumo D G and Olaoye J. A (2001). "Roles and Problems of Small Scale Business Development Programs in Nigeria", Department of Business Administration, University of Ilorin

Adejumo, G. (2001). Indigenous entrepreneurship development in Nigeria: Characteristics, problems and prospects. Advances in Management: Journal of Department of Business Administration, University of Ilorin, Nigeria, 2(1), 112-122.

Adejumo, G (2001) Indigenous entrepreneurship development in Nigeria: Characteristics, problem and prospects, Journal of Business Administration, 2(1): 112-122

Agboli, M. \& Ukaegbu, C. C. (2006). Business environment and entrepreneurial activity in Nigeria: Implications for industrial development. Journal of Modern African Studies. 44(1), 1-30.

Akanji, O. O. (2001). Microfinance as strategy for poverty reduction. Central Bank of Nigeria Economic and Financial Review, 39(4), 111-134.

Akanni, O.W (2008) Entrepreneurship in Nigeria: Problem challenges and prospects, Nigeria management review, A Journal of the Centre for Management Development, 14 (1\& 2) 
Alvarez, S. A. \& Busenitz, L. W. (2001). The entrepreneurship of resource-based theory. Journal of Management, $27,755-775$.

Anderson, A. \& Miller, C. (2003). Class matters: Human and social capital in the entrepreneurial Process. Journal of Social Economics, 32, 17-36.

Ariyo, D. (2005). Small firms are the backbone of Nigerian economy. Retrieved from http://www.africaeconomicanalysis.org

Aremu, M.A. (2004) Small scale enterprises: Panacea to poverty problem in Nigeria, Journal of Management and Enterprise development, 1 (1)

Baron, R. A. \& Henry, R. A. (2010). How entrepreneurs acquire the capacity to excel: Insights from research on expert performance. Strategic Entrepreneurship Journal 4(1), 49-65.

Barreto, H. (2014), the Entrepreneur in Microeconomic Theory: Disappearance and Explanation. London: Rout ledge Publications

Berglann, H., Moen, E., Roed, K. \& Skogstrom, J. F. (2009). Entrepreneurship: Origins and returns. IZA Discussion Paper No. 4250. Retrieved from http:/iza.org/dp4250 pdf.

Carland, J. W., Hoy, F., Boulton, W. R., et al. (1984). Differentiating entrepreneurs from small Business owners: A conceptualization. Academy of Management Review, 9(2), 354-359.[11]. Central Bank of Nigeria (2001). Banking Supervision Annual Report. CBN, Abuja, Nigeria.

Drucker, P (1985) The practice of management: London, Heinemann

Harper, M. (1991). The role of enterprise in poor countries. Entrepreneurship, Theory and Practice, 15(4), 7-11.

Hornby, A.S (2006) Oxford advanced learner's dictionary: Oxford, Oxford University

Kirzner, I. M (1973): Competition and Entrepreneurship, Chicago, University of Chicago.

Onwumere, j. (2000). The nature and relevance of SMEs in economic development, The Nigerian Banker-Journal of the Chartered Institute of bankers of Nigeria Vol. 25.

Morris, M. H. \& Lewis, P. S. (1991), Entrepreneurship as a significant factor in social quality of life.

Schumpeter. J. A., Redvers. O. (1983) (1934): The theory of economic development: An inquiry into profits, capital, credit, interest, and the business cycle, New Brunswick, New Jersey, Transaction Books, Translated from the 1911 original German, Theorie der wirtschaftlichen Entwicklung.

Smith, A. [1776] (1937): An Inquiry into the Nature and Causes of the Wealth of Nations, New York, Modern Library.

Sullivan, B. C and Ikpeze, N. (1980). "Problem of industrial growth in Nigeria”. In Amucheazi, C. Publishing Co. 